\title{
The extraordinary undergraduate career of Oliver St John Gogarty: has the modern medical student anything to learn from him?
}

\author{
S O'Mahony \\ Consultant Gastroenterologist, Cork University Hospital, Cork, Ireland
}

\begin{abstract}
Oliver St John Gogarty (1878-1957) was a celebrated Irish doctor and poet. A 'Renaissance' figure, he was renowned as a surgeon, poet, memoirist, senator, athlete and wit. His years as a medical student, although not crowned by academic success, were remarkable for many other achievements. A study of Gogarty's University career provides a number of lessons in the art of being a medical student. Although it is more than a century since Gogarty qualified as a doctor, this paper suggests that these lessons are still relevant today.
\end{abstract}

\author{
Correspondence to S O'Mahony \\ Cork University Hospital \\ Wilton, Cork \\ Ireland
}

tel. $+353(0) 214922378$

e-mail Seamus.omahony@hse.ie

KEYWORDS Oliver St John Gogarty, medical education, medical humanities

DECLARATIONS OF INTERESTS No conflicts of interest declared.

\section{INTRODUCTION}

Oliver St John Gogarty (1878-1957) (Figure I) was an Irish surgeon and writer.' He was an intimate friend of James Joyce and WB Yeats, and is probably now best known as the model for the character 'Buck' Mulligan in Joyce's Ulysses. ${ }^{2}$ He wrote lyric poetry of a high quality which was greatly admired by Yeats, who famously included more poems by Gogarty than by any other living author when he edited The Oxford Book of Modern Verse (1936). ${ }^{3}$ As a senator in the Parliament (Oireachtas) of the new Irish Free State, Gogarty was a vociferous opponent of Eamonn de Valera's government, and he campaigned for better living conditions for the slumdwellers of Dublin. He survived an attempt on his life by Republican gunmen by diving into the river Liffey. He developed a lucrative private practice in ear, nose and throat surgery, and was a celebrated wit and conversationalist. In later years, he became disillusioned with the new Irish state, and after losing a libel action connected to his memoir As I Was Going Down Sackville Street, ${ }^{4}$ he moved to New York, where he died in 1957. Gogarty is now a somewhat forgotten figure, and his poetry seldom features in anthologies. In later life, he was embarrassed to be identified as the inspiration for 'Buck' Mulligan.

\section{GOGARTY THE MEDICAL STUDENT}

In all Gogarty spent ten years as a medical student. He left several records of these years, including the novel Tumbling in the Hay, ${ }^{5}$ a thinly-veiled autobiographical piece, as well as three volumes of official autobiography. ${ }^{4,6,7}$ Although Gogarty began his studies at the Royal

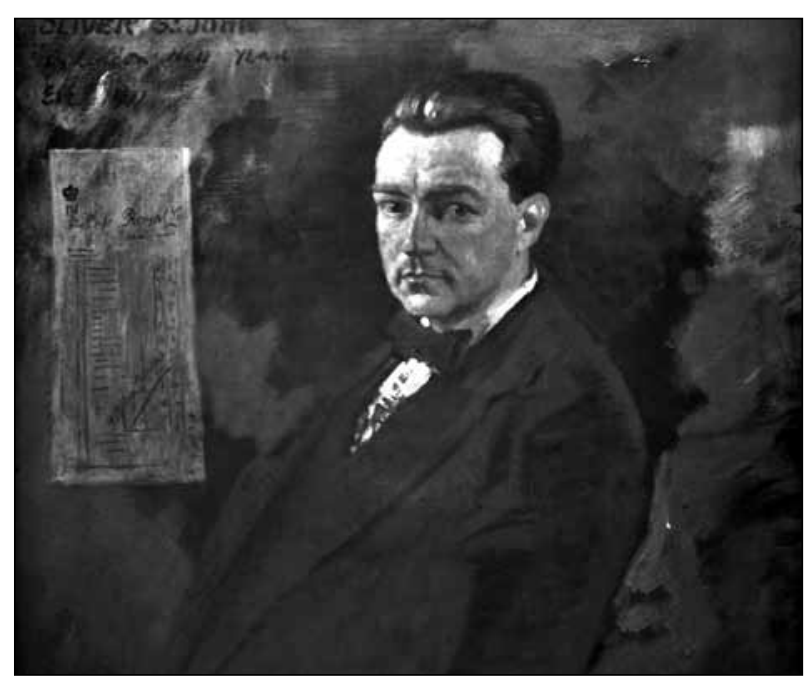

FIGURE I Portrait of Oliver St John Gogarty by William Orpen. Reproduced with the permission of the Royal College of Surgeons in Ireland.

University in Dublin (now University College Dublin), he moved after two years to Trinity College Dublin. During his two years at the Royal, Gogarty managed to pass only two out of ten examinations; he spent much of his time cycling and carousing with his fellow medical students. James Joyce, younger by two years and an Arts student at the Royal, was also part of Gogarty's inner circle. Trinity College was then a predominantly Protestant institution, and it was unusual for a Catholic, such as Gogarty, to study there; however, his academic performance at the Royal University was so dire that his mother was persuaded to enrol him at Trinity, where his father had also studied medicine. It was during his time at Trinity that Gogarty became a famous Dublin 
personality. His serious lyric poetry regularly won college prizes, but it was his bawdy limericks and scurrilous doggerel which did the rounds in Dublin and gave him an instant notoriety. A gifted classicist, fluent talker and superb mimic with a gift for memorising poetry, Gogarty became the favourite of such famous dons as Mahaffy, Tyrell and Macran. He was a highly competitive athlete taking part in cycling races at a high level, and later taking up flying. A strong swimmer, he rescued drowning people from the Liffey on several occasions, for which he was awarded the bronze medal of the Royal Humane Society.

Medical education has now become almost exclusively vocational and utilitarian, with large numbers of students taught in a factory-style environment. The undergraduate career of Gogarty reminds us of a time when education was broader, when medical students mixed easily with classicists and historians. No student ever took more advantage of this environment than Oliver St John Gogarty. Although medical education has changed dramatically in the century since Gogarty qualified, a study of his undergraduate career provides lessons which may be useful for the modern student.

\section{LESSON NO. I: TAKE ADVANTAGE OF ALL THE EDUCATIONAL OPPORTUNITIES A UNIVERSITY HAS TO OFFER}

Good-looking, witty, well read - Gogarty was lionised by the Trinity Fellows like no other student since Oscar Wilde. John Pentland Mahaffy was the most famous of these Trinity Fellows, a colossal figure who excelled in classics, music, history and Egyptology. ${ }^{8}$ With a combination of cheek and erudition, Gogarty charmed Mahaffy, who even forgave him for writing satirical verses about him, mocking, amongst other things, Mahaffy's snobbery and inability to pronounce his 'r's. Gogarty called Mahaffy 'The Master', and so intimate were they that they had nicknames for each other: Mahaffy was 'Fafner' and Gogarty 'Fasolt' - Fafnir and Fasolt were mythological figures who featured in Wagner's opera Das Rheingold. Gogarty was a frequent guest at the Master's rooms. His idol, however, was Robert Yelverton Tyrrell, a charismatic classicist, whom Gogarty referred to as 'The Divine Doctor'.Tyrrell first invited Gogarty to his rooms for wine when Gogarty sat an examination in English literature. Medical students at Trinity College at that time sat for the BA after three years (even today, medical students at Trinity are awarded a BA after successful completion of their pre-clinical studies). Gogarty had pointed out a technical fault in Tennyson's Locksley Hall, which greatly impressed Tyrrell: 'Tyrrell it was who awarded me the maximum ten marks in my examination for English in the BA, but that was merely a preliminary reason for my love and admiration. He was the wittiest man of his day..." Gogarty was served wine by a liveried waiter, while The Divine Doctor drank whiskey. Through Tyrrell, Gogarty met HS Macran, Professor of Moral Philosophy. Macran, at that time the world's greatest authority on Hegel, tutored Gogarty in philosophy, and the two became lifelong friends. Edward Dowden, who taught English at Trinity, had written definitive biographies of Goethe and Shelley. He awarded the Vice-Chancellor's Prize for poetry to Gogarty in three successive years (1902, 1903, 1904), a Trinity record. Gogarty was very keen on poetry prizes indeed, on prizes and medals of all kinds, taking the Bronze medal for literature at the 1924 Paris Olympic games. (Competitions in the arts were a feature of the modern Olympics until 1948). In the 1928 Tailteann Games he won the gold medal for poetry. (The Tailteann Games, the Irish Free State's answer to the Olympic Games, were held in 1924, 1928 and 1932, and were open to competitors of Irish birth or ancestry $\left.{ }^{9}\right)$.

Mahaffy, Tyrrell, Macran and Dowden deeply influenced the young Gogarty, and inspired in him a love for classical literature which was to inform his poetry and his conversation: 'I am easily influenced by those I admire." He adapted complex ancient Greek metrical and rhyming systems for his poetry, and looked to the Classical world for inspiration. The dons saw in Gogarty the embodiment of the Classical ideal: poet, athlete, physician, man of action. He remained friends with all four dons long after he left Trinity College.

\section{LESSON NO. 2: TAKE UP SPORT}

Gogarty's sport of choice was cycling, although he was a good footballer and a strong swimmer. He turned out as a semi-professional footballer for Preston North End Reserves when he was a schoolboy at Stonyhurst, in Lancashire, and later, when he was a medical student, played for Bohemians in Dublin.

Road cycle races were dangerous affairs, with serious injury a frequent occurrence. Trinity students were strongly discouraged from taking part in these races; the preferred sports for young gentlemen were cricket and rowing. Gogarty's cycling career was disapproved of by his family and his teachers, and he gave it up having been banned for swearing. Throughout his later life, he had a passion for speed, first in cars (Figure 2), and later as an aviator. He gained a private pilot's licence and was a founder member of the Irish Aero Club. (Later, at the start of WW II, he applied to join the Royal Air Force, but was turned down on age grounds).

Like 'Buck' Mulligan, he delighted in swimming, and frequently began his working day with a plunge into the sea in Dublin Bay, regardless of the season. For all his love of the life of the mind, Gogarty took an almost Pagan delight in sport and physical activity, and his 


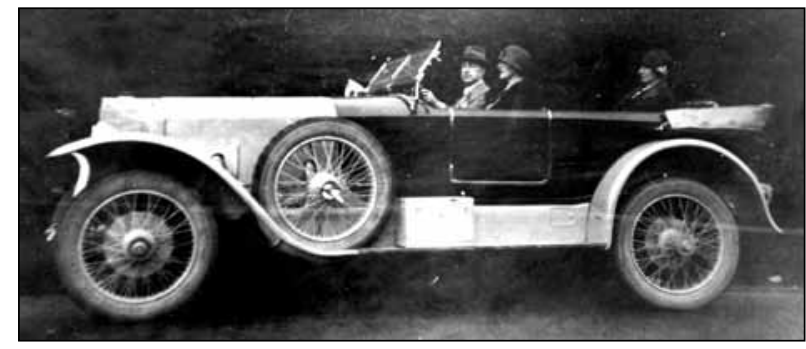

FIGURE 2 Oliver St John Gogarty, his sister-in-law and her sister in his Rolls Royce. Reproduced with the permission of the Royal College of Surgeons in Ireland.

physical fitness gave him the energy in later life to pursue many different activities. It was undoubtedly his physical fitness which saved his life when he escaped assassination. Liam Lynch, an anti-Treaty IRA commander had ordered that Free State Senators be shot on sight. Gogarty was kidnapped in 1923 by anti-Treaty militants, who held him in an empty house near Chapelizod to await his fate. He broke free from his captors and escaped by plunging into the icy waters of the river Liffey.

\section{LESSON NO. 3: MAKE FRIENDS WITH STUDENTS FROM OTHER DISCIPLINES}

Stately, plump Buck Mulligan came from the stairhead, bearing a bowl of lather on which a mirror and razor lay crossed. A yellow dressing-gown, ungirdled, was sustained gently behind him by the mild morning air. He held the bowl aloft and intoned:

\section{- Introibo ad altare Dei}

Halted, he peered down the dark winding stairs and called up coarsely:

- Come up, Kinch. Come up, you fearful Jesuit.

The opening lines of Joyce's Ulysses are nearly as well known as those of Pride and Prejudice and Anna Karenina, and they immortalised Gogarty. Joyce and Gogarty shared a Martello tower in Sandycove, Dublin, along with Samuel (later Dermot) Chevenix-Trench (Haines in Ulysses) (Figure 3). (Martello towers were constructed along the coastline of the British Isles in the early 1800s in preparation for a French invasion.) Joyce and Gogarty had met some years previously (when Joyce was studying Arts at the Royal University) and had developed a close friendship based on a shared love of poetry, mockery and carousing in the Kips (Dublin's red light district); Joyce, the younger man, looked up to Gogarty, admiring his panache and style. Gogarty rented the tower partly with the intention of providing a quiet environment for Joyce to write. The opening chapter of Ulysses captures something of Gogarty's personality - his 'coarse vigour'. Malachi (Buck) Mulligan is a Regency figure: the aristocratic Anglo-Irish 'Bucks' of Georgian Ireland were infamous for their drinking, gambling and

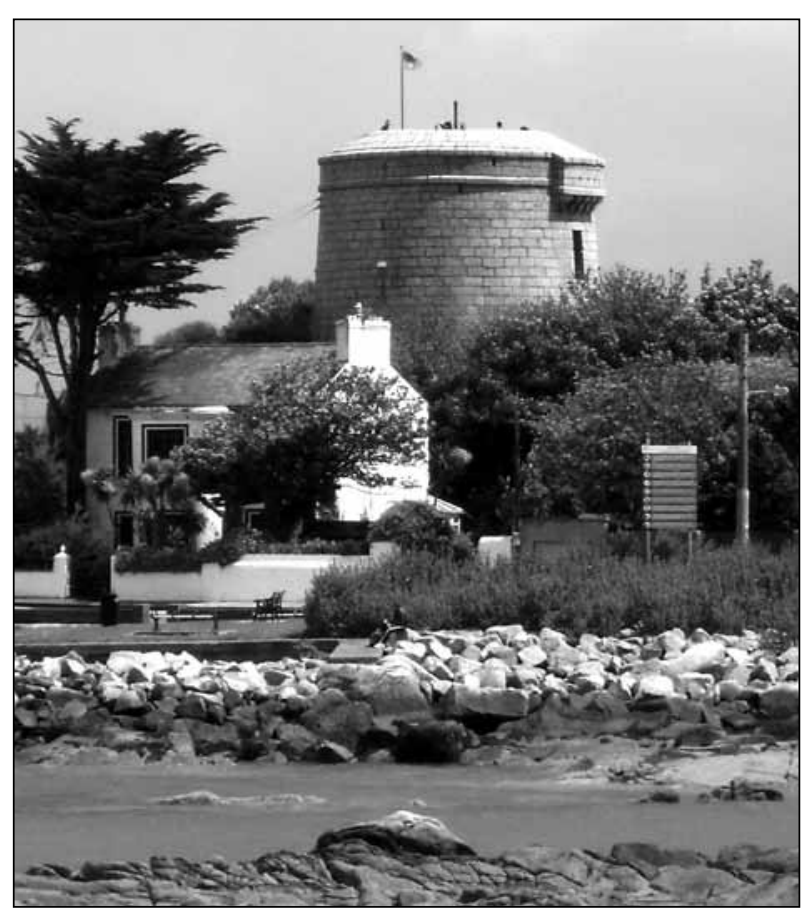

FIGURE 3 Martello tower in Sandycove, Dublin, which was rented by Gogarty is now a James Joyce Museum. Image courtesy of the James Joyce Museum, Dublin.

dissipation. Buck is a show-off, lampooning the ecclesiastical Latin of the Roman Mass, quoting classical Greek ('Thalatta! Thalatta!'), Swinburne ('Isn't the sea what Algy calls it: a grey sweet mother?'), and his own scatological musings ('The snotgreen sea. The scrotum tightening sea'). Although Mulligan is full of life and language ('two dactyls, tripping and sunny, like the Buck himself') pours from him like a torrent, one can sympathise with Joyce's alter ego, Stephen Dedalus, who is clearly irritated and bored by Mulligan. Gogarty was incensed by his portrayal in Ulysses, and believed it impugned his reputation. He was also deeply antagonistic to modernism in literature: in the first chapter of his volume of autobiography, It Isn't This Time OfYear At All!, he attacks the Joycean style: ' 'It may be a pity that this book is not in the modern mode of writing, that is, without a hero, without any serial sequence, without meaning and without unity except the unity of whatever comes into the writer's head.' In Ulysses, Mulligan admonishes Dedalus for refusing to pray at his mother's death-bed, and they part on bad terms. Joyce and Gogarty, too parted on bad terms: "I was living with him and his constant air of reprobation and his reserve and silences annoyed me, for I took them to be a pose; and I detest humbug in any manifestation. ${ }^{7}$ Gogarty finished his medical studies, and Joyce left for Zurich with Nora Barnacle to pursue his calling as a writer. Gogarty later attempted to repair the friendship when Joyce visited Dublin, but the meeting was not a success. He did not approve of the academic industry which grew up around Joyce's work, and resisted all attempts to make him part 
of the Joycean cavalcade. By the time Ulysses appeared in 1922, Gogarty was a fashionable surgeon and a senator; he did not want the world to know of his lessthan-respectable student days.

Joyce's global reputation and fame is assured, yet for most readers, Oliver St John Gogarty is now known only as the model and inspiration for Buck Mulligan. Towards the end of his life, Gogarty was dismayed to be sought out by Joyce scholars keen to meet Malachi Mulligan.'I was called by one of his critics "An accessory before the fact of Ulysses", wrote Gogarty, 'That, of course, is an extenuation of the truth. To know a man intimately does not make you an accessory to his subsequent action."

\section{LESSON NO. 4: CULTIVATE FRIENDS OUTSIDE MEDICINE WHO WILL PROMOTE YOUR CAREER}

During his student years, Gogarty established close friendships with WB Yeats (I3 years his senior) and George Moore (26 years older). How did a gregarious medical student become so intimate with two famous, older writers? Gogarty's mother, although widowed young, had regular 'at homes', and it was at one such 'at home' that Gogarty met Yeats. The older poet was impressed by Gogarty's classical knowledge, and like the dons at Trinity, relished Gogarty's high spirits and wit. Yeats, as editor of The Oxford Book of Modern Verse, ${ }^{3}$ famously included more poems by Gogarty than by any other living poet. In the preface to the book, he defended this decision: 'Twelve years ago (in January 1923), Oliver Gogarty was captured by his enemies, imprisoned in a deserted house on the edge of the Liffey with every prospect of death. Pleading a natural necessity he got into the garden, plunged under a shower of revolver bullets and as he swam the ice-cold December stream promised it, should it land him in safety, two swans. I was present when he fulfilled that vow. His poetry fits the incident, a gay, stoical - no, I will not withhold the word - heroic song. Irish by tradition and many ancestors, I love though I have nothing to offer but the philosophy they deride, swashbucklers, horsemen, swift indifferent men. That is the reason, though perhaps not the only one, why I have given Gogarty such space, and I think him one of the great lyric poets of our age.' Although Gogarty admired Yeats deeply, he was not afraid to mock the great man.

George Moore was a world-famous novelist when he first met Gogarty; he had returned from London to his native Ireland in 190I, and his house in Ely Place became a meeting point for writers, artists and politicians. Moore, who was old enough to be Gogarty's father, was fascinated and captivated by the precocious articulacy of the young medical student. The writer ' $\mathbb{E}$ ' (George Russell) observed: 'when he
(Gogarty) came into the room, Moore had the rare experience of being out-talked in his own house.'

Through Yeats and Moore, Gogarty became friendly with many wealthy and titled people, such as Lord Dunsany, Lady Fingall, the Earl of Granard and Lady Leslie. Like his mentor Mahaffy, he was unashamed in his regard and admiration for the aristocracy ('I love a lord'), and was assiduous in cultivating the social contacts which would later help establish his private practice.

\section{LESSON NO. 5: BECOME INVOLVED IN POLITICS}

Gogarty's biographer, Ulick O'Connor, concluded that Gogarty's closest friend was Arthur Griffith, founder and leader of Sinn Fein. Gogarty met Griffith, six years his senior, in 1899 at 'An Stad', a tobacconists and meeting place for students and nationalists. Griffith was as reserved as Gogarty was loquacious, but they established an unlikely friendship, and the undergraduate Gogarty was a frequent contributor to Griffith's paper The United Irishman. Griffith led the Irish delegation which negotiated the Anglo-Irish Treaty in 1921, leading to the foundation of the Irish Free State. After the signing of the Treaty, a bitter and bloody civil war broke out between pro- and anti-Treaty forces. Griffith died (probably of a subarachnoid haemorrhage), aged 50 at the height of this conflict, and Michael Collins was assassinated ten days later. Gogarty attended Griffith during his final illness. Gogarty was an unlikely nationalist, having little sympathy for the Gaelic Revival which was such a part of the independence movement in Ireland at the time. Like Griffith, however, he believed that Irish independence should be achieved by non-violent means. Gogarty was devastated by Griffith's death; Ulick O'Connor observed that Gogarty was never quite the same man afterwards. Gogarty was not by nature a socialist - his political views were almost Nietzchean, but his experiences as a medical student (particularly his obstetric attachment at Holles Street Hospital) influenced him deeply. Later, as a Senator (1922-36), he campaigned passionately for proper housing for Dublin's poor: 'The proletariat produce the slums and the slums produce the deathrate; and the Corporation tolerates it all. ${ }^{5}$ Under the pseudonym 'Alpha and Omega' he wrote Blight, a play about poverty in the Dublin slums, which was produced at the Abbey Theatre in 1917. The play attracted full houses, but was closed after only ten days, possibly because of political pressure on the Abbey's directors.

\section{LESSON NO. 6: IN THE END, YOU HAVE TO GROW UP}

Gogarty, for all his gaiety and high spirits, had, I believe, a melancholic core to his nature. He presented a mask to the world: it is difficult to imagine Buck Mulligan and 


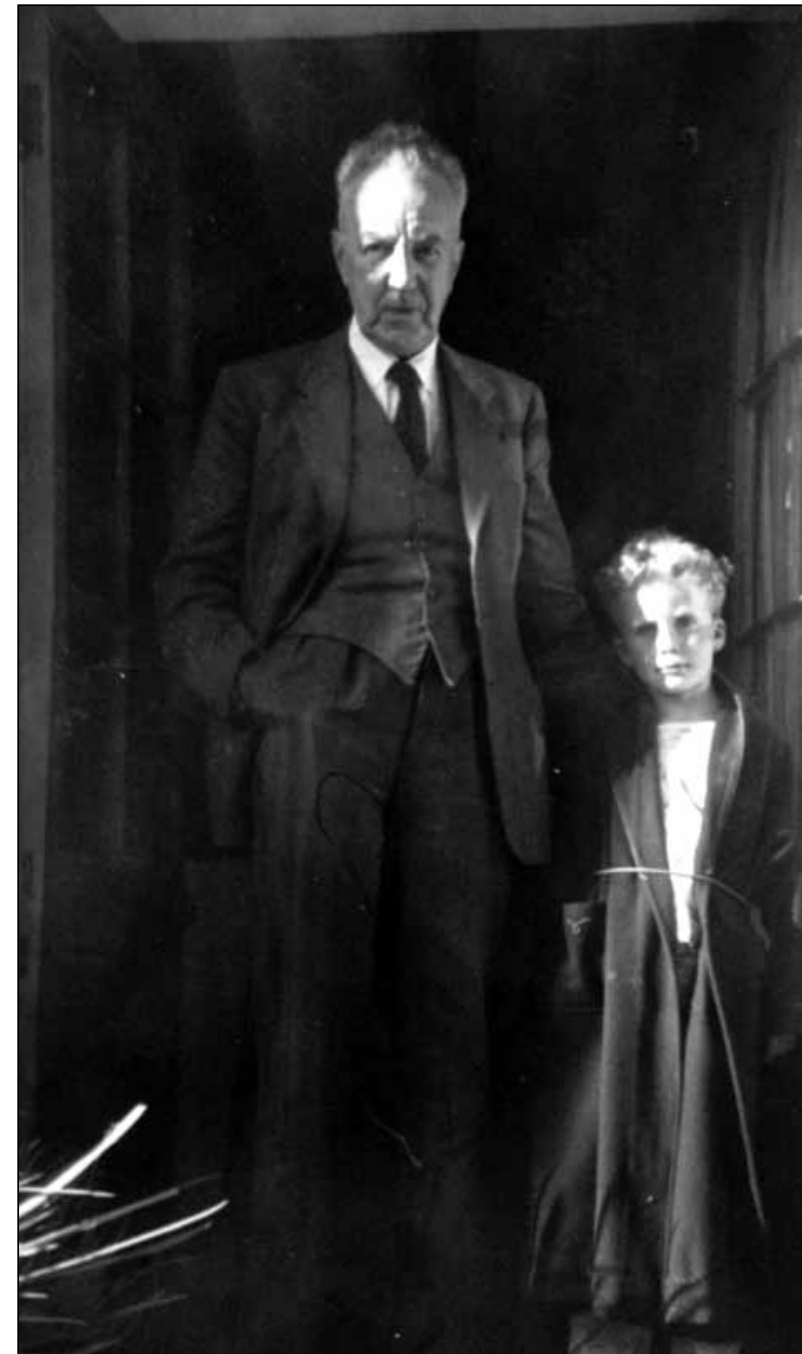

FIGURE 4 Oliver St John Gogarty with his grandson Guy Williams. Reproduced with the permission of the Royal College of Surgeons in Ireland.

Sigmund Freud in conversation. Ironically for such a famous talker, he kept his innermost thoughts to himself. A telling anecdote sums up Gogarty's armour: having embalmed and laid out the body of his closest friend, Arthur Griffith, Gogarty attended a party later that evening where he was observed to be "his gay, sparkling self again'.'

His medicine clerkship was under the tutelage of Dr Joseph O'Carroll at the Whitworth Hospital. Gogarty described O'Carroll as 'a humourless martinet', yet in Tumbling in the Hay, Gogarty gives O'Carroll an address to the students which encapsulates Gogarty's own credo: ${ }^{5}$

Turn back now if you are not prepared and resigned to devote your lives to the contemplation of pain, suffering and squalor. For realise that it is not with athletes that you will be consorting, but with the dying and the diseased. The sunny days will not be yours any longer but days in the crowded dispensaries, the camp of the miner or of the soldier where, unarmed, you must render service in the very foremost positions. ... Your faces will alter. You will lose your youthful smirks; for, in the end, your ceaseless traffic with suffering will reflect itself in grave lines upon your countenance. Your outlook on life will have none of the deception that is the unconscious support of the layman: to you all life will appear in transit, and you will see with clear and undeceived vision the different stages of its devolution and its undivertible path to the grave... These are no delightful thoughts, but they will inevitably be yours, and your recompense for them is that your work for a short space may ease pain and baulk, if only for a year or two, the forces of annihilation and decay...

I have seen as the years of experience progress the wildest medicos, the greatest rapscallions, turn themselves into good, sober and sound physicians. It is by Charity that this miracle is wrought. By Charity. You know too much. You know what suffering means. You have seen it perhaps at the acutest and most pitiable stage of all when it turns delirious in its attempts at wild delight. You have seen what the wages of sin are.

For this you must be prepared to sacrifice more than your lives. You must sacrifice your delight in Beauty; for, as you gaze on it, your knowledge tempts you to see beneath its bloom the intimations of decay. This is the price that you must pay for your knowledge. This is the sacrifice you must make. Your joy in life must be exchanged for devotion to the service of mankind. Unselfishly to make this sacrifice is the long-descended tradition and prerogative of our profession...Good morning.

Despite his early failures in medical examinations and a life packed with a host of diverse activities, Gogarty had a successful career as a surgeon at the Meath Hospital. Here he would delight in flamboyant antics in the operating theatre, such as throwing into the viewing gallery a larynx he had just excised. In his private ENT consulting rooms in Ely Place, he charged substantial fees to wealthy patients while treating the less well-off for free.

\section{CONCLUSION}

Perhaps Gogarty is not the ideal role model for the modern medical student: his academic record - at least in medicine - was undistinguished, and some of his extracurricular activities, were, to put it delicately, Rabelasian. Nevertheless, there is much for the modern medical student to learn from his career. Modern medical education is essentially vocational, and narrow in its focus. There is currently no consensus on how the 
humanities should be incorporated into an already overcrowded medical curriculum. Gogarty's story shows another way: medical students should be given free access to the humanities departments within their own university, and should be allowed to take intercalated arts degrees, just as many now take in sciences such as physiology and biochemistry.

Gogarty's undergraduate career shows how interests and friendships developed at medical school can sustain a doctor over a lifetime. His years as a medical student set the pattern for his subsequent career. Gogarty grasped with both hands the educational opportunities provided by his university. He established the intimate friendships with fellow students, distinguished dons, nationalist politicians and famous writers which were to last all his life. He learned not just how to be a doctor, but also how to be a writer, a politician, a talker, a sportsman, a celebrity. Gogarty's autobiographical writings are suffused with a sense of nostalgia for this lost, golden youth. In The Old Goose (1924), ${ }^{10}$ a mockheroic poem, Gogarty's theme is that old age is redeemed by a 'ranging youth' (Figure 4):

\section{REFERENCES}

O'Connor U. Oliver St John Gogarty. London: Jonathan Cape; 1964. Joyce J. Ulysses. Paris: Sylvia Beach; 1922.

3 Yeats, WB (editor). The Oxford book of modern verse 1892-1935. Oxford: Oxford University Press; 1936.

4 Gogarty O St J. As I was going down Sackville Street. London: Rich \& Cowan; 1936.

5 Gogarty O St J. Tumbling in the hay. London: Constable; 1939.

6 Gogarty O St J. Rolling down the lea. London: Constable; 1950.

7 Gogarty O St J. It isn't this time of year at all! London: McGibbon \& Kee; 1954.
Love life and use it well:

That is the tale they tell,

Who broke it like a shell,

And won great glory.

But you and I are both

Inglorious in sloth

Unless our ranging youth

Redeem our story.

'The fox', wrote the Greek poet Archiclochus," 'knows many things, but the hedgehog knows one big thing.' Gogarty was the archetypical fox. With his multiple job titles (surgeon, poet, athlete, senator, and more) Gogarty was a restless, energetic man who never quite excelled in any of these activities. Some have speculated that had he concentrated on just one area, he might have achieved the fame of contemporaries such as Joyce and Yeats. ${ }^{12}$ Gogarty was undoubtedly attracted to fame, but what mattered more to him was the Greek ideal of living life to the full.
8 Stanford WB, McDowell RB. Mahaffy: a biography of an AngloIrishman. London: Routledge \& Kegan Paul; 197I.

9 Brennan C. The Tailteann Games, 1924-1936 [Internet]. [cited 2012, Nov 6]. Available from: www.the irishhistory.com/20II/ 02/23/the-tailteann-games-1924-1936/

10 Gogarty O St J. An offering of swans. Dublin: Cuala Press; 1924.

II Berlin I. The hedgehog and the fox. An essay on Tolstoy's view of history. London:Weidenfeld \& Nicolson; 1953.

12 Killeen T. Mercurial Malachy. The Irish Times 2002 Jan 5. 